\title{
Observations on auroræ boreales witnessed at Bedford, at various times, from April 19, 1830, to January 11, 1831
}

\section{W.H. White H.M.C.S.}

To cite this article: W.H. White H.M.C.S. (1831) Observations on auroræ boreales witnessed at Bedford, at various times, from April 19, 1830, to January 11, 1831, Philosophical Magazine Series 2, 9:53, 393-395, DOI: 10.1080/14786443108647639

To link to this article: http://dx.doi.org/10.1080/14786443108647639

曲 Published online: 27 Jul 2009.

Submit your article to this journal $₫$

ЏلI Article views: 2

View related articles 
made through it by means of a hot coal, and not by percussion, which would disturb the crystals; the liquid metal is then to be poured out: in about half an hour the remainder of the crust may be broken, and the crystals will be found in great perfection.Journal de Pharmacie, 1830, p. 534.

REACTION OF PERSALTS OF IRON AND CARBONATES.

M. Sorbeiran finds that the persalts of iron decomposed by neutral carbonates yield a carbonate of peroxide equally neutral: this carbonate is soon destroyed to produce a double salt, formed by the neutral alkaline sulphate and the subsulphate of iron, yielding a new sulphate of iron, before unknown, and containing three times as much base as the neutral salt : a weak alkali in excess precipitates another subsalt, which has not been before noticed, but is a true double salt, composed of the subsulphate of iron and the hydrated peroxide. The aperient saffron of Mars is a hydrate of the peroxide of iron, containing 3 atoms of water mixed with variable and accidental quantities of sesquicarbonate of iron, and sometimes neutral carbonate of iron.-Ibid. 1830 , p. 535 .

INFLAMMATION OF PHOSPHORUS BY CHARCOAL.

Dr. Bache of Philadelphia states, that, at the temperature of $60^{\circ}$ Fahr. or upwards, carbon in the form of animal charcoal or lampblack causes the inflammation of a stick of phosphorus powdered with it: the effect takes place either in the open air, or in a close receiver of a moderate size.-Silliman's Journal, xviii. 373.

OBSERVATIONS ON AURORE BOREALES WITNESSED AT BEDFORD,

AT VARIOUS TIMES, FROM APRIL 19, 1830, TO JANUARY 11,

1831. BY W. H. WHITE, H.M.C.S.

To the Editors of the Philosophical Magazine and Annals.

Gentlemen,

The frequent appearance of the auroræ boreales at Bedford, lat. $52^{\circ} 8^{\prime} 48^{\prime \prime}$ north, long. $2^{\prime} 49^{\prime \prime}$ east, may perhaps form some apology for my troubling you with a short account of them. The first that I observed was on the 19th of April, 1830. Soon after sunset a bright light appeared in the horizon about the magnetic north, which in creased in brightness as the twilight decreased. I watched it till a little after nine P.M., before any coruscations could be distinguished, when a few faint flame-coloured flashes darted about $12^{\circ}$ or $14^{\circ}$ above the horizon about the north-west. About eleven P.M. several columns of light rose in the north-west in quick succession, which continued for upwards of an hour; some of them extended as far as the north, and were slightly tinged with red. During the appearance of the aurora up to midnight, several bright meteors appeared above it, but none of them were visible more than two seconds.

Sept. 7 th.-A little before the moon rose I observed an aurora which extended from the north nearly to the north-west, from which emanated several columns of light; the rising moon soon overpowered its light, so that I could not distinguish any other coruscations.
N.S. Vol. 9. No. 53. May 1831.
$3 \mathrm{E}$
Sept. 
Sept. 8th.-The aurora again appeared, more extended than on the preceding evening. I watched it for upwards of half an hour, when clouds intervened and prevented further observation.

Sept. 17 th.-The aurora borealis again appeared, soon after eight P.M., in the horizon between the north-west and north-by-east, from which emanated seven or eight reddish columns of light, two of which reached the star Benetrasch in Ursa major. Soon after nine P.M. the aurora disappeared.

Oct. 5. - At a quarter past seven P.M. an aurora again appeared between the north and north-west. A few very thin columns of light emanated. About eight p.M. a few coruscations were visible, but the rising of the moon overpowered them in light.

Oct. 16.- About half-past nine P.M. the aurora again appeared about the magnetic north, from which several columns of light, slightly tinged with red, emanated, and attained the altitude of about. $40^{\circ}$. In one hour no traces of the aurora were visible.

Oct. 17.-An aurora again appeared and bore a strong resemblance to a morning twilight ; no coruscations were visible, and it soon disappeared.

Nov. 1.-A little before nine P.M. a bright aurora was visible between the north and west points of the horizon ; soon after nine, notwithstanding the moon shone very brightly, several columns of light: darted up near the magnetic north, some of which attained the height of $20^{\circ}$. Clouds intervened about half-past nine, and the aurora was no longer visible.

Nov. 4.-An aurora appeared soon after seven P.M., which extended from the north nearly to the west. About eight a few columns of light were perceptible. The rising of the moon prevented any further observation, and the aurora soon disnppeared. Two very bright meteors appeared soon after eight.

Nov. 7.-A faint aurora was visible for more than two hours, but no coruscations were distinguished. One bright meteor appeared about half-past seven.

Dec. 11.-At seven P.M. a very bright aurora borealis appeared between the north-west and north-by-east points of the horizon; at eight, clouds intervened, but at nine the sky again became clear, and very large columns of red light were seen to rise quite to the zenith; it increased in splendour till past midnight. Some of the columns appeared as if tinged with black, and had the resemblance of dense columns of smoke. Two persons who were guarding their master's property against the attacks of incendiaries, assured me that the red columns continued to play in every direction, and on every point of the compass between the east and west, till past four A.M. A respectable gentleman in this neighbourhood, who has been an attentive ob. server of meteorological appearances for upwards of forty years, assured me, that he never recollected during that period the Northern Lights so powerful in this country, nor did he ever observe so many meteors in any one night in his life-time; the number he could not ascertain, but he thought nearly twenty.

Dec. 12.-The aurora again appeared at six P.M. between the north. 
north-east and north-west, but few coruscations were visible till about ten P.M., when several columns of white light darted in quick succession up to the zenith. Huge masses of white light, if I may so term them, rose in the north-west, and, as it were, sailed majestically along the horizon to the true north, and some as far as north-east, and then shot up in massy columus. These appearances lasted till half-past eleven, when the aurora began to diminish in brightness, and in about two hours disappeared. 'Two bright meteors appeared in the north.

Dec. 13.-The aurora again appeared light in strong twilight, but no coruscations were visible.

Dec. 14.-At six P.M. the aurora was again visible, but fainter than on the preceding evening.

Jan. 7, 1831.-An aurora borealis appeared in the north-east, which had a reddish tinge, and had a similar effect to the rising moon on a hazy evening. At a quarter past five a zone of white light rose from the centre of the aurora, passed over the Pleiades just below Aries, and to the west-south-west point of the horizon, forming a complete arc. After remaining in a perfect state for about three minutes, the centre of the bow began to disappear, and in a few seconds the whole vanished. Several patches of white light were afterwards formed in the south-east and south-west, which remained for some time. At twenty minutes past five, perpendicular columns of red and white light darted up to the zenith, and some even passed the zenith and reached Orion, having an altitude of about $30^{\circ}$ south. At half-past five the northern hemisphere appeared to be covered with a complete canopy of various coloured lights, which extended from north-east to west, and exhibited one of the most magnificent appearances ever witnessed in this latitude. Columns of light continued to emanate till past midnight. The aurora did not finally disappear till about four A.M.

Jan. 8.-An aurora was again visible for about two hours, but no coruscations were visible.

Jan. 11.-Was a very cloudy evening, but having occasion to go out about ten o'clock, the northern parts of the heavens appeared unusually light; the clouds dispersed, and an aurora presented itself extending from north to north-west; two or three coruscations were visible, but clouds again intervened, and at eleven the aurora could no longer be seen.

N.B. After the auroræ in November and December, we had strong gales of wind from the south and south-west; but since the appearances of the present year we have had a calm.

Should these notices, copied from my journal, merit a place in your Magazine, your insertion of them may cause naturalists in different parts of the country to make some useful remarks upon them. I have the honour to be, Gentlemen,

Your most obedient Servant,

Bedford, W. H. Whate, H.M.C.S.

January 12th, 1831 . 